\title{
Arahan Optimasi Penggunaan Lahan Melalui Pendekatan Telapak Ekologis di Kabupaten Gresik
}

\author{
Achmad Ghozali1 \\ Prodi Perencanaan Wilayah dan Kota \\ Institut Teknologi Sepuluh Nopember, Surabaya, Indonesia \\ Putu Gde Ariastita \\ Prodi Perencanaan Wilayah dan Kota \\ Institut Teknologi Sepuluh Nopember, Surabaya, Indonesia
}

\begin{abstract}
Abstrak: Daya dukung lingkungan Kabupaten Gresik mengalami ketidakseimbangan dalam mewadahi setiap peningkatan kegiatan akibat pertumbuhan penduduk dan perubahan guna lahan yang semakin intensif. Ditandai dengan adanya ketidakseimbangan antara supply daya dukung lingkungan dan konsumsi sumber daya alam dimana perubahan penggunaan lahan di Kabupaten Gresik berakibat pada kerusakan ekologis seperti penurunan produktivitas lahan, krisis air, bencana banjir, dan pencemaran lingkungan. Penelitian ini bertujuan untuk mengetahui komponen daya dukung optimasi penggunaan lahan di Kabupaten Gresik. Metode yang digunakan adalah melalui pendekatan telapak ekologis dimana dapat diukur tingkat konsumsi sumber daya alam dan kemampuan lahan dalam menyediakan kebutuhan konsumsi tersebut dalam satuan lahan global hektar (gha). Hasil penelitian menunjukkan bahwa biokapasitas Kabupaten Gresik mencapai 319.179,6 gha yang banyak tersebar di wilayah periurban. Prosentase biokapasitas tertinggi pada jenis lahan pertanian sebesar 53.92\%. Meskipun demikian biokapasitas tersebut tidak sebanding dengan konsumsi telapak ekologis yang mencapai 1.63 juta gha terutama pada wilayah urban akibat tingginya populasi dan aktivitas kegiatan. Hal ini memperkuat kondisi ketidakseimbangan daya dukung lingkungan di Kabupaten Gresik yang sudah mengalami defisit ekologis sebesar 1.04 gha/kapita. Semua jenis lahan mengalami kondisi deficit dan hanya jenis lahan peternakan yang mengalami kondisi surplus sebesar 0.05 gha/kapita. Hasil pemetaan kondisi defisit ekologis menunjukkan bahwa optimasi penggunaan lahan perlu dilakukan dengan penerapan pembangunan kota kompak (Compact City) sehingga pembangunan mudah dikendalikan dan terjadi efisiensi penggunaan energi. Selain itu juga perlu penerapan sistem agropolitan melalui peningkatkan produktifitas lahan pada wilayah peri urban sebagai supply sumber daya utama di wilayah Kabupaten Gresik.
\end{abstract}

Kata kunci: lahan, optimasi lahan, telapak ekologis

Abstract: Environmental capacity in Gresik Regency is imbalance condition in accommodating every increase of activity due to population growth and intensive land use change. It is marked by the disproportion between environmental capacity and nature resource consumption where the land use change in Gresik Regency gave impact to ecological damage such as land productivity degradation, water scarcity, flood, and environmental pollution. This research aims to determine the carrying capacity components in the optimization of land use in Gresik Regency. The method used is through ecological

1 Korespondensi Penulis: Prodi Perencanaan Wilayah dan Kota ITS Surabaya
Email: achmad_kmf@yahoo.com 
footprint approach that can be used to measure nature resource consumption rate and land capability in providing that needs in global hectare land (gha) unit. The result of this research showed that Gresik biocapacity reached 319.179,6 gha that is widely spread in the peri-urban area. The highest biocapacity percentage is on agricultural land with $53,92 \%$. However, that biocapacity is not comparable to the ecological footprint consumption that reached 1,63 million gha especially in urban area due to the high population and activity intensity. This worsen the imbalance of carrying capacity in Gresik Regency that has been already experienced ecological deficit for 1,04 gha/capita. Every land types is experiencing deficit condition and only ranch farm land that has surplus of 0,05 gha/capita. The mapping result showed that land use optimization is needed by implementing compact city development so that it can be easier to control and create energy use efficiency. Besides of that, agropolitan system implementation is needed to increase land productivity in peri-urban area as major resources in Gresik Regency.

Kata kunci: ecological footprint, land, land optimization

\section{Pendahuluan}

Bertambahnya penduduk mengakibatkan peningkatan kebutuhan aktivitas (demand) yang diikuti oleh pemanfaatan sumber daya alam yang terus meningkat (Arsyad, dkk, 2008). Hal ini mengakibatkan eksploitasi lahan yang berlebihan, perubahan tata guna lahan yang tidak terkendali, menurunnya daya dukung lingkungan dan ketersediaan air (Kodoatie, 2010). Sumber daya alam mempunyai batas daya dukung yang terbatas baik kuantitas, kualitas dan kontinyuitas untuk mendukung penggunaan lahan secara optimal. Sehingga penggunaan lahan yang tidak memperhatikan kaidah lingkungan akan sangat menganggu kelangsungan sumber daya alam, kerusakan lahan, penurunan produktivitas lahan dan meningkatkan masalah sosial seperti kelaparan dan kemiskinan (Kodoatie, 2005; Widiatmaka, 2007 dan Arsyad, 2008).

Di samping itu, pembangunan seharusnya ditujukan untuk memperbesar manfaat lingkungan dengan tetap memperhatikan keseimbangan lingkungan pada setiap perubahan tata guna lahan (Soemarwoto, 2004). Salah satu implementasi konsep daya dukung lingkungan untuk pembangunan berkelanjutan adalah melalui pendekatan telapak ekologis (Retnowati, 2011). Kajian telapak ekologis merupakan pendekatan perhitungan daya dukung lingkungan suatu wilayah melalui perhitungan konsumsi total populasi dan limbah buangan yang dihasilkan oleh aktivitas penduduk tersebut dengan ketersediaan sumber daya alam (Wackernagel dan Ress, 1996). Pendekatan telapak ekologis ditujukan untuk menunjukkan ketergantungan hidup manusia terhadap alam tempat hidup serta mengamankan kapasitas sumber daya alam untuk keberadaan manusia di masa mendatang (Dirjen PU, 2010).

Berdasarkan Rencana Tata Ruang Wilayah (RTRW) Kabupaten Gresik Tahun 20102030 disebutkan bahwa telah terjadi persoalan pemanfaatan ruang antara lain penurunan luas lahan terbuka secara signifikan. Pada periode tahun 2002-2008, telah terjadi penurunan luas lahan sawah, tanah kering dan tambak masing-masing sebesar sebesar 2.251,82 ha, 1.546,67 ha dan 5.491,91 Ha. Kondisi tersebut menimbulkan beberapa persoalan lingkungan. Penelitian Prasita (2007) menemukan bahwa sejak tahun 1999 produktivitas tambak di wilayah pesisir Kabupaten Gresik mengalami penurunan akibat pencemaran air laut oleh akumulasi limbah industri dan limbah kegiatan budidaya perikanan. Berdasarkan data Dinas Pertanian, Perkebunan dan Kehutanan Kabupaten Gresik produktivitas lahan sawah tahun 2007 sebesar 6,1 ton/ha namun pada tahun 2011 sudah turun menjadi 5,5 ton/ha. 
Berdasarkan hasil kajian LAPAN (2005) menemukan bahwa Kabupaten Gresik merupakan salah satu daerah yang akan mengalami kondisi tidak seimbang akibat pertumbuhan penduduk dan perubahan penggunaan lahan. Dengan rata-rata pertumbuhan penduduk sebesar 2,3\%, prediksi tersebut dapat menjadi kenyataan. Persoalan ini juga diperkuat oleh hasil temuan Dirjen PU (2011) bahwa Kabupaten Gresik sudah termasuk dalam status warning. Eksploitasi sumber daya alam hayati hampir mencapai klimaks dimana pada tahun 2011 konsumsi telapak ekologis sudah melebihi biokapasitas dengan selisih 0.9 gha disertai adanya indikasi kerusakan lingkungan yang dapat menghambat supply kebutuhan konsumsi penduduk (Dirjen PU, 2011).

Dengan demikian pengembangan yang terjadi di Kabupaten Gresik akibat pertumbuhan penduduk dan peningkatan aktivitas ekonomi mengindikasikan telah terjadi ketidakseimbangan lingkungan. Kondisi tersebut tentu bertentangan dengan tujuan umum pembangunan yaitu untuk memenuhi kebutuhan penduduk agar dapat bertahan dan melanjutkan hidup, serta meningkatkan kualitas hidupnya (Irwan, 2005). Menurut Soeriatmadja (1981) sebuah wilayah dapat berkembang secara sehat jika dalam wilayah tersebut berlaku dinamika keseimbangan dalam proporsi penggunaan lahan bagi berbagai keperluan. Oleh karena itu, Pemanfaatan ruang di Kabupaten Gresik seharusnya dilakukan secara optimum dimana setiap komponen aktivitas dalam unit ruang tersebut berinteraksi secara maksimal sesuai daya dukung kawasan yang pada akhirnya memberikan manfaat sebesar-besarnya kepada seluruh pihak yang berkepentingan secara berkelanjutan (Rusli dkk, 2010). Untuk itu perlu dilakukan penelitian mengenai keseimbangan lingkungan di Kabupaten Gresik melalui pendekatan telapak ekologis untuk mendukung pembangunan berkelanjutan.

\section{Metode Penelitian}

Tujuan dari penelitian ini adalah untuk mengetahui kondisi komponen daya dukung lingkungan di Kabupaten Gresik sehingga dapat menjadi dasar rumusan optimasi penggunaan lahan yang berkelanjutan. Metode yang digunakan adalah melalui pendekatan telapak ekologis dimana dilakukan perhitungan terhadap konsumsi sumber daya alam dan kemampuan lahan dalam menyediakan kebutuhan konsumsi tersebut dalam satuan lahan.

Pada tahap awal akan dilakukan analisis kondisi supply (biokapasitas) setiap jenis penggunaan lahan di Kabupaten Gresik dan analisis kondisi demand konsumsi sumber daya alam (telapak ekologis) melalui perhitungan matematis telapak ekologis. Selanjutnya dilakukan analisis kondisi keseimbangan lingkungan di Kabupaten Gresik melalui perbandingan kondisi supply dan demand hasil analisis sebelumnya. Pemetaan dilakukan untuk mengetahui kondisi masing-masing wilayah secara spasial.

Data yang digunakan adalah data primer yang diperoleh dengan menyebarkan kuisioner rumah tangga untuk mengetahui konsumsi pangan dan energi, sedangkan data sekunder diperoleh dari dokumen-dokumen instansi terkait seperti Bappeda, Dinas Pertanian, Perkebunan dan Kehutanan, Dinas Pternakan, Perikanan dan Kelautan, Badan Lingkungan Hidup dan Dinas PU Cipta Karya dan Tata Ruang.

\section{Konsep Telapak Ekologis}

Telapak ekologis mengukur total biaya ekologis (dalam area lahan) dari suplai seluruh barang dan jasa kepada penduduk yang menunjukkan bahwa penduduk tidak hanya secara langsung memerlukan lahan untuk produksi pertanian, jalan, bangunan dan lainnya, akan tetapi secara tidak langsung lahan pun turut mewujudkan barang dan jasa yang dikonsumsi penduduk (Constanza, 2000). Sedangkan pada sisi kebutuhan, telapak ekologis merupakan 


\section{Arahan Optimasi Penggunaan Lahan Melalui Pendekatan Telapak Ekologis di Kabupaten Gresik}

luasan lahan yang dibutuhkan untuk memenuhi konsumsi penduduk dan menyerap limbah buangan yang dihasilkan oleh aktivitas penduduk tersebut (Wackernagel dan Ress, 1996). Murray (2003) mengklasifikasikan lahan jenis konsumsi sumber daya alam oleh manusia yaitu pangan, perumahan, transportasi, dan lahan-lahan barang konsumsi seperti pertanian, hutan, dan perikanan.

Dengan pendekatan ini, perhitungan kualitas wilayah dikonversikan sebagai luasan area bioproduktif standar. Luasan bioproduktif diartikan sebagai semua luasan lahan yang berkontribusi terhadap biokapasitas yang memberikan pasokan konsentrasi biomasa secara ekonomis (GFN-USA, 2012). Area ini mencakup 6 (enam) kategori lahan, yaitu lahan pertanian, lahan peternakan, lahan kehutanan, lahan perikanan, lahan terbangun dan lahan penyerap karbon (GFN-USA, 2012). Area bioproduktif ini disebut dengan global hektar (gha). Setiap global hektar mewakili sejumlah area bioproduktif yang sama. Setiap golongan area memiliki faktor ekuivalen sendiri berdasarkan area produktif standar, yaitu rata-rata produktivitas dari 11,2 milyar hektar bioproduktif di bumi (Wackernagel et. $\mathrm{Al}$, 2005).

Dengan demikian telapak ekologis terdiri dari 4 (empat) unsur penting yaitu populasi, area lahan, produktivitas (hasil/ha) dan konsumsi sumber daya lahan (ha/kapita), yang hasil perhitungannya akan menjadi bagian dalam perhitungan daya dukung suatu wilayah (Retnowati, 2010). Berdasarkan metode yang telah dikembangkan oleh Global Footprint Network (GFN) (2012) dalam Guidebook to the National Footprint Accounts 2011 Edition, biokapasitas (BK) untuk semua kategori lahan dihitung dengan menggunakan persamaan berikut:

Dimana :

$$
\mathrm{BK}_{\mathrm{L}}=\mathrm{A} . \mathrm{YF} . \mathrm{EQF}
$$

BK : Biokapasitas

A : Luas lahan dari setiap kategori lahan

YF : yield factor (factor panen)

EQF : Equivalenc factor (ekuivalensi jenis kategori lahan)

Sementara itu konsumsi dihitung dari konsumsi bersih yang merupakan konsumsi aktual yang dipengaruhi oleh kegiatan perdagangan (ekspor-impor) dalam persamaan berikut :

$$
\mathrm{EF}=\left(\mathrm{P} / \mathrm{Y}_{\mathrm{N}}\right) \cdot \mathrm{YF} \cdot \mathrm{EQF}
$$

Karena, $\mathrm{YF}=\mathrm{Y}_{\mathrm{N}} / \mathrm{Y}_{\mathrm{W}}$, maka rumus EF dapat disederhanakan sebagai berikut :

Dimana :

$$
\mathrm{EF}=\mathrm{P} / \mathrm{YW} \cdot \mathrm{EQF}
$$

EF : Telapak ekologis

$\mathrm{P} \quad$ : Jumlah produk dipanen atau limbah yang dihasilkan

(konsumsi dalam luasan)

$\mathrm{Y}_{\mathrm{N}} \quad$ : Produktifitas kategori lahan wilayah perhitungan

$\mathrm{Y}_{\mathrm{W}} \quad$ : Produktifitas kategori lahan dunia

Dalam perhitungan telapak ekologis (TE) dan perhitungan biokapasitas (BK), digunakan 2 (dua) faktor konversi, yaitu:

1. Faktor Penyama (equivalent factor)

Faktor penyama merupakan faktor yang mengkonversi satuan lokal tertentu menjadi satuan universal, yaitu hektar global (gha). Faktor penyama telah ditentukan oleh Global 
Footprint Network untuk 5 (lima) kategori lahan, yaitu lahan pertanian (2.51), lahan hutan (1.26), lahan peternakan (0.46), lahan perikanan (0.37) dan lahan terbangun (2.51). Faktor ini diukur dari tingkat keberlanjutan jenis lahan dan ketergantungan populasi terhadap kategori lahan tersebut.

2. Faktor Panen (yield factors)

Berdasarkan metode yang dikembangkan GFN (2012) yang juga mengacu pada Borucke et all (2012), faktor panen merupakan rasio antara produktivitas suatu kategori lahan suatu wilayah dengan rata-rata produktivitas kategori lahan yang sama di dunia dan pada tahun yang sama. Seperti rumus berikut :

$$
\mathrm{YF}_{L}=\frac{Y_{N, i}}{Y_{W, i}}
$$

Keterangan :

$\mathrm{YF}_{\mathrm{L}} \quad$ : Faktor panen (yield factor) untuk kategori lahan $\mathrm{L}$

$\mathrm{Y}_{\mathrm{NL}} \quad$ : Produktivitas lahan (yield) kategori lahan L di wilayah perhitungan

$\mathrm{Y}_{\mathrm{WL}} \quad$ : Produktivitas lahan (yield) dunia untuk produk i.

Meskipun demikian, terdapat beberapa asumsi perhitungan yield factor untuk beberapa jenis kategori lahan (Borucke et all, 2012) antara lain ;

1. Lahan terbangun memiliki yield factor yang sama dengan lahan pertanian dikarenakan asumsi bahwa lahan perkotaan biasa mengkonversi lahan pertanian.

2. Lahan penyerap karbon memiliki yield factor yang sama dengan lahan hutan dikarenakan keterbatasan data dan informasi mengenai penyerapan karbon untuk jenis penggunaan lahan lainnya.

3. Lahan perikanan memiliki nilai yield factor 1 atau produktifitas lahan perikanan dunia sama dengan wilayah perhitungan. Hal ini karena keterbatasan data perikanan dunia terlebih pada negara atau wilayah pedalaman. Organisasi FAO hanya mampu menghimpun data perikanan di 57 negara dunia.

\section{Hasil dan Pembahasan}

\section{Kondisi Biokapasitas Wilayah Kabupaten Gresik}

Dari hasil analisis Kabupaten Gresik memiliki biokapasitas sebesar 319,179.6 gha untuk mencukupi kebutuhan konsumsi telapak ekologis. Prosentase terbesar biokapasitas adalah berasal dari jenis lahan pertanian dengan 53.92 \% atau 22,252 gha. Prosentase biokapasitas terkecil adalah dari jenis lahan hutan. Hal ini diakibatkan oleh luas lahan yang minim dan produktifitas lahan hutan juga tidak sebanding dengan produktifitas lahan dunia. Hal ini berbanding terbalik dengan lahan pertanian yang lebih besar secara luassan dan produktifitas lahan pertanian juga lebih baik. Dengan demikian supply kebutuhan pertanian di Kabupaten Gresik lebih dapat terlayani daripada kebutuhan produk kehutanan.

Biokapasitas lahan terbangun juga tinggi seiring pertumbuhan lahan terbangun yang mengkonversi lahan pertanian. Biokapasitas lahan terbangun sebesar $23.88 \%$ atau sebesar 76,231.41 gha. Hal ini menggambarkan intensitass kegitan yang cenderung tinggi dan akan mempengaruhi konsumsi sumber daya alam di Kabupaten Gresik. Besarnya lahan terbangun ini lebih besar dari biokapasitas lahan peternakan dan perikanan yang masingmasing sebesar $3.39 \%$ dan $0.17 \%$.

Dari Gambar 1 dapat diketahui bahwa Kecamatan Gresik merupakan kecamatan dengan biokapasitas terkecil yaitu hanya sebesar 225.37 gha dan hanya terdiri dari biokapasitas lahan peternakan. Ketiadaan lahan pertanian di Kecamatan Gresik menjadikan 


\section{Arahan Optimasi Penggunaan Lahan Melalui Pendekatan Telapak Ekologis di Kabupaten Gresik}

biokapasitas lahan pertanian dan bangunannya nol. Hal ini menunjukkan bahwa tidak ada supply pertanian terhadap aktivitas pada lahan terbangun.

Secara agregat biokapasitas tertinggi terdapat di Kecamatan Balongpanggang dimana memiliki nilai biokapasitas sebesar 43,334.94 gha. Meskipun dipengaruhi oleh luasan wilayah yang besar namun ketersediaan semua kategori lahan dengan produktifitas pertanian yang tinggi menjadikan kecamatan ini secara supply mampu mendukung kegiatan di setiap jenis penggunaan lahan.

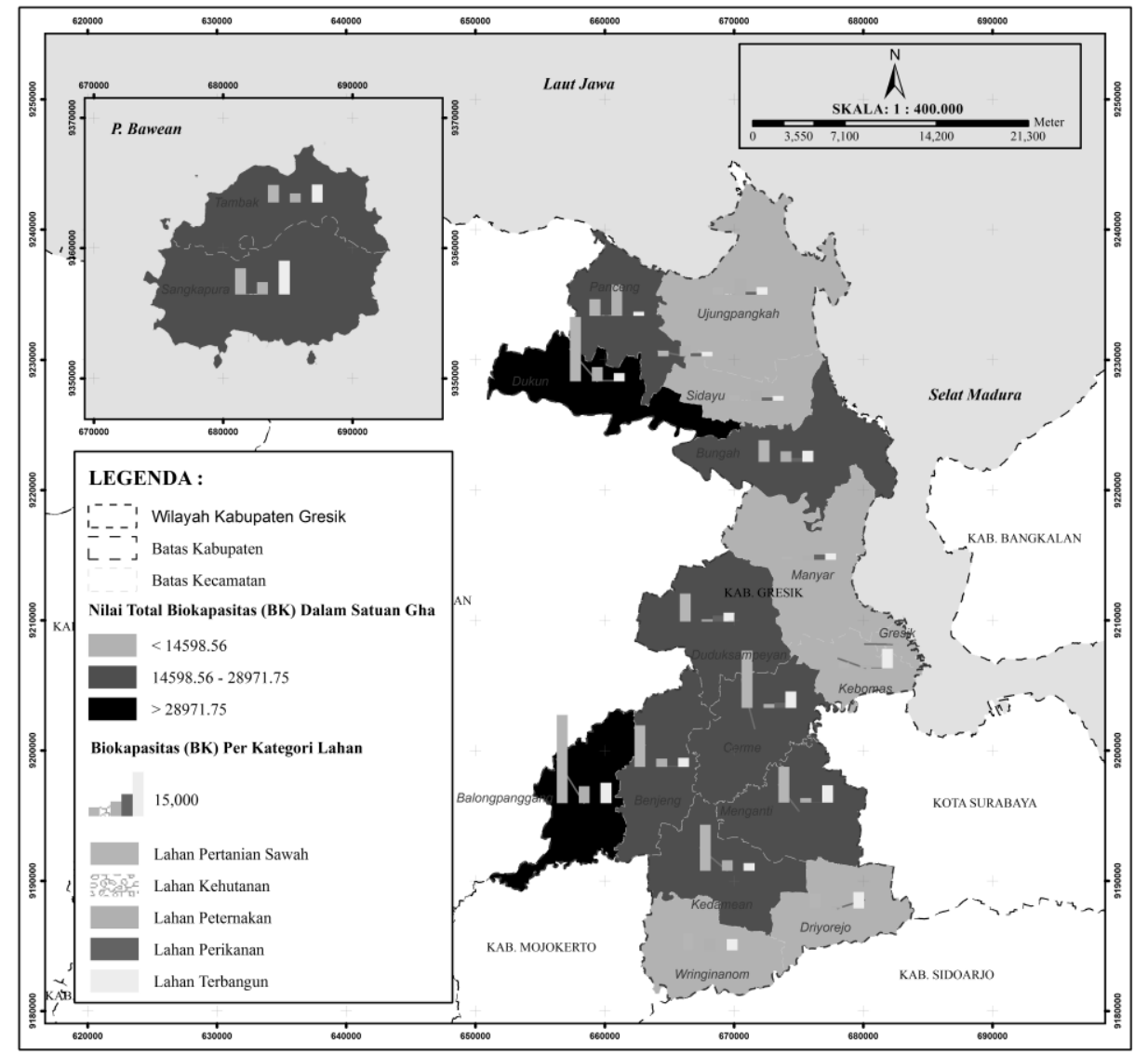

\section{Gambar 1. Tipologi Wilayah Berdasarkan Tingkat Biokapasitas di Kabupaten Gresik}

Dari gambar tersebut dapat diketahui bahwa wilayah bagian selatan Kabupaten Gresik relatif memiliki biokapsitas besar dari wilayah lain. Hal ini tidak terlepas dari biokapasitas lahan pertanian di masing-masing kecamatan wilayah tersebut yang juga tinggi. Sementara itu biokapasitas lahan perikanan tinggi terdapat di wilayah bagian tengah Kabupaten Gresik. Wilayah tersebut merupakan kecamatan dengan luas perikanan dan produktifitas perikanan tinggi daripada wilayah lain. Selain itu biokapasitas lahan kehutanan terbesar berada di Pulau Bawean. Jika dibandingkan secara keseluruhan, kecamata dengan biokapasitas tertinggi adalah Kecamatan dengan lahan pertanian yang besar karena pada pendekatan telapak ekologis menganggap lahan pertanian memiliki tingkat keberlanjutan yang paling tinggi sebagai lahan pangan utama. Pada kecamatan dengan lahan perikanan besar seperti Kecamatan Manyar dan Ujungpangkah cenderung memiliki biokapasitas yang lebih rendah. 


\section{Kondisi Telapak Ekologis Wilayah Kabupaten Gresik}

Perhitungan telapak ekologis dihitung berdasarkan konsumsi pangan, energi, tingkat emisi CO2, dan konsumsi kayu. Dari hasil analisis diketahui bahwa kondisi telapak ekologis tertinggi adalah pada lahan pertanian dengan $73 \%$. Kemudian lahan kehutanan dan lahan bangunan dengan $20 \%$ dan $5 \%$. Telapak ekologis terkecil berada pada lahan peternakan dimana kurang dari $0.05 \%$. Dengan demikian penggunaan lahan di Kabupaten Gresik seharusnya mampu mengakomodasi kebutuhan prioritas pada lahan pertanian, kehutanan dan bangunan. Khusus pada lahan bangunan yang biasa mengkonversi jenis lahan lahan lain harus dikendalikan meskipun kebutuhannya tinggi baik untuk permukiman maupun industri dan perdagangan.

Pada lahan pertanian, meskipun jenis lahan ini mendominasi penggunaan lahan di Kabupaten Gresik namun kebutuhan akan pangan yang tinggi menjadikan telapak ekologis lahan pertanian menyumbangkan angka tertinggi pada telapak ekologis secara keseluruhan. Pada Gambar 2 menunjukkan bahwa wilayah perkotaan memiliki konsumsi telapak ekologis yang tinggi dari wilayah lain seperti Kecamatan Gresik, Manyar, Kebomas, Menganti, Cerme dan Driyorejo. Hal ini tidak terlepas dari intensitas penduduk yang tinggi di wilayah perkotaan Gresik.

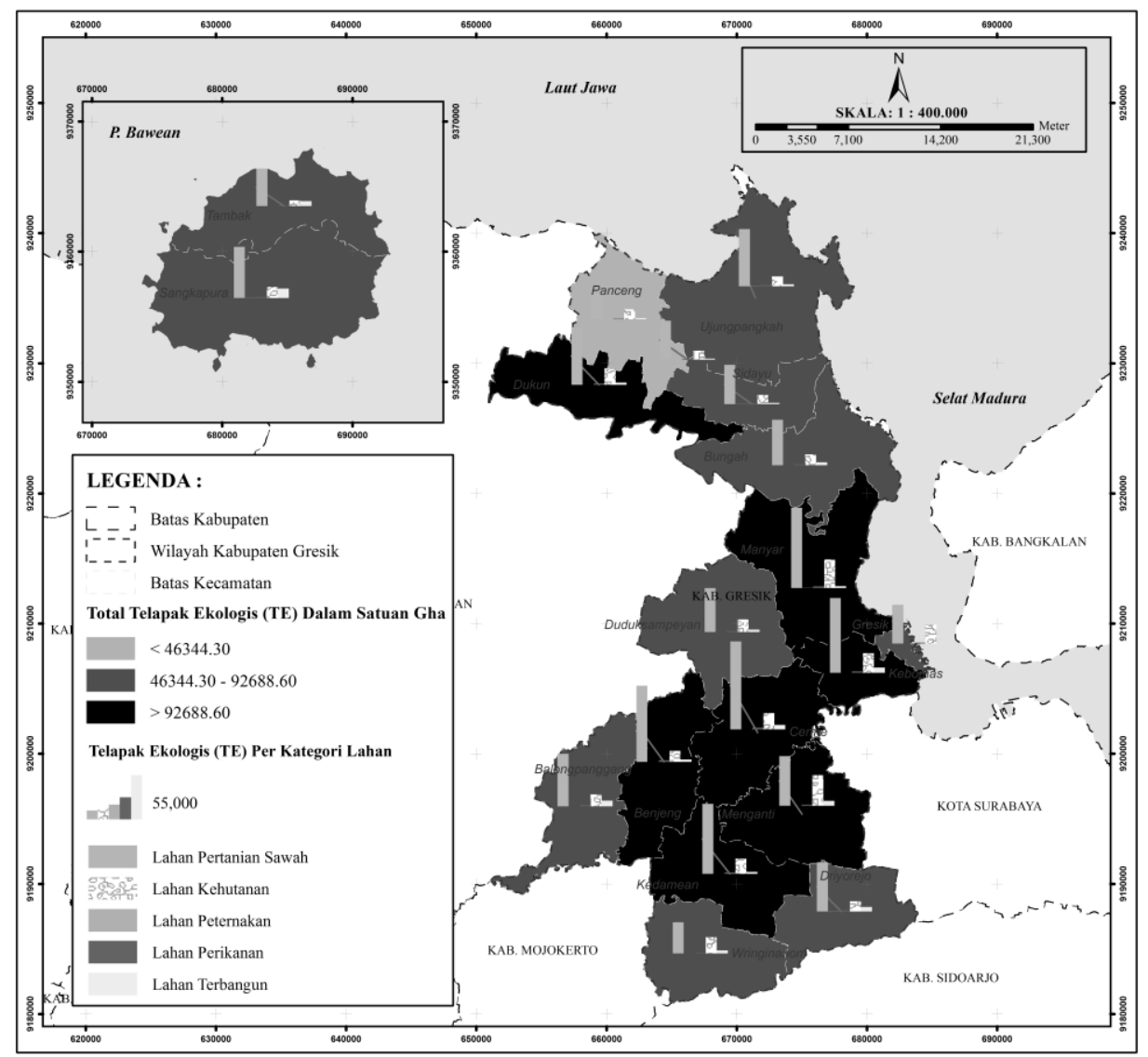

Gambar 2. Tipologi Wilayah Berdasarkan Tingkat Telapak Ekologis di Kabupaten Gresik 


\section{Arahan Optimasi Penggunaan Lahan Melalui Pendekatan Telapak Ekologis di Kabupaten Gresik}

\section{Kondisi Daya Dukung Wilayah Kabupaten Gresik}

Analisis ini dilakukan dengan membandingkan nilai biokapasitas perkapita dengan telapak ekologis perkapita di masing-masing wilayah seperti pada Tabel 1 berikut (dalam gha/kapita). Dari tabel ini dapat diketahui bahwa hanya lahan perikanan dan peternakan yang mengalami kondisi seimbang sedangkan jenis lahan lain mengalami defisit. Meskipun demikian secara keseluruhan total TE perkapita dan BK perkapita mengalami defisit yang cukup signifikan.

Tabel 1. Kondisi Keseimbangan Ekologis Masing-Masing Kategori Lahan Telapak Ekologis di Kabupaten Gresik

\begin{tabular}{l|r|r|r|l}
\hline \multicolumn{1}{c|}{ Kategori Lahan } & $\begin{array}{c}\text { TE } \\
\text { Perkapita }\end{array}$ & BK Perkapita & $\begin{array}{c}\text { Defisit } \\
\text { Ekologis }\end{array}$ & \multicolumn{1}{|c}{ Kondisi } \\
\hline Lahan Pertanian & 0.95 & 0.14 & 0.81 & Moderat Defisit \\
\hline Lahan Kehutanan & 0.26 & 0.00 & 0.26 & Minor Deficit \\
\hline Lahan Peternakan & 0.00 & 0.05 & -0.05 & Balance Region \\
\hline Lahan Perikanan & 0.02 & 0.01 & 0.01 & Balance Region \\
\hline
\end{tabular}

Jika dilihat pada setiap wilayah kecamatan seperti pada Gambar 3 maka akan terlihat perbedaan kondisi daya dukung masing-masing wilayah. Pada lahan pertanian, setiap kecamatan mengalami defisit ekologis yang sangat signifikan dimana biokapasitas yang ada tidak sebanding dengan telapak ekologis lahan pertanian. Hal ini sangat terlihat pada kecamatan perkotaan Gresik yang memiliki defisit tertinggi yaitu berkisar antara 0.5-0.9 gha/kapita terutama di Kecamatan Gresik yang tidak memiliki biokapasitas lahan pertanian. Pada wilayah kecamatan yang merupakan lumbung produksi padi di Kabupaten Gresik seperti Kecamatan Balongpanggang, Cerme, Benjeng, Dukun dan Pulau Bawean juga mengalami defisit ekologis masing-masing sebesar 0.6, 1.19, 0.73 dan 0.99 gha/kapita. Dengan demikian konsumsi beras sudah melebihi lahan pertanian sawah dalam menyediakannya sehingga perlu adanya manajemen lahan untuk peningkatan produksi pangan lahan pertanian.

Pada lahan peternakan, masing-masing kecamatan kecuali Kecamatan Gresik mengalami kondisi surplus dimana biokapasitas lebih besar daripada telapak ekologis peternakan. Telapak ekologis masing-masing kecamatan berkisar antara 0.001-0.002 gha/kapita. Surplus tertinggi berada di Kecamatan Panceng sebesar 0.21 gha/kapita. Surplus terendah berada di Kecamatan Driyorejo dan Manyar yang masing-masing mengalami konidisi surplus sebesar 0.01 gha/kapita. Secara agregat Kabupaten Gresik mengalami kondisi surplus sebesar 0.05 gha/kapita. Dengan demikian konsumsi produk pertanian penduduk Kabupaten Gresik masih jauh di atas produksi alamnya.

Kondisi berbeda terjadi pada lahan kehutanan. Masing-masing kecamatan memiliki kondisi defisit yang sangat mencolok dengan defisit sebesar 0.1-0.3 gha/kapita. Kondisi ini terjadi akibat kebutuhan kayu yang tinggi sedangkan produksi hutan yang dimiliki tidak sebanding. Hasil analisis kebutuhan lahan hutan lebih banyak terserap untuk kebutuhan konsumsi kayu daripada lahan penyerap karbon. Luas lahan hutan produksi yang minim sedangkan kebutuhan yang tinggi menjadikan secara agregat Kabupaten Gresik mengalami defisit ekologis kehutanan sebesar 0.26 gha/kapita.

Pada lahan perikanan, masing-masing kecamatan mengalami kondisi yang berbeda meskipun total Kabupaten Gresik mengalami defisit ekologis sebesar 0.01 gha/kapita. Kecamatan Duduksampeyan, Sidayu, dan Bungah mengalami kondisi surplus ekologis 
lahan perikanan masing-masing sebesar $0.02,0.003$ dan 0.001 gha/kapita. Hal ini diakibatkan oleh luas dan produktifitas lahan perikanan di masing-masing kecamatan relatif lebih tinggi daripada kecamatan lain, sedangkan kecamatan dengan kondisi defisit tertinggi adalah Kecamatan Kedamean dengan defisit ekologis sebesar 0.032 gha/kapita.

Hasil yang berbeda jika dilihat dari biokapasitas dan telapak ekologis secara keseluruhan. Masing-masing wilayah kecamatan mengalami kondisi defisit ekologis dengan rentang antara 0.7- 1.5 gha/kapita. Sementara itu Kabupaten Gresik secara keseluruhan mengalami kondisi defisit sebesar 1.04 gha/kapita. Dengan demikian, berdasarkan kualifikasi tingkat defisit ekologis dari China Council for International Cooperation on Environment and Development-World Wide Fund for nature (CCICED-WWF) tahun 2006 maka Kabupaten Gresik termasuk kondisi severe deficit (sangat kurang).

Meskipun demikian terdapat kecamatan-kecamatan yang masih termasuk moderate deficit yang dapat dipertimbangkan dipertahankan sebagai wilayah perdesaan seperti pada Gambar 3 antara lain Kecamatan Dukun, Panceng, Bungah, Balongpanggang, Menganti, Wringinanom dan Sangkapura. Meskipun beberapa kecamatan perkotaan termasuk moderate deficit namun sumber daya lahan wilayah perkotaan sudah tidak mendukung kebutuhan sumber daya alam penduduknya. Kecamatan Sidayu dan Ujungpangkah merupakan wilayah bukan perkotaan namun memiliki defisit ekologis yang besar. Hal ini bukan berarti tingginya konsumsi telapak ekologis di wilayah tersebut namun jika dilihat pada penggunaan lahannya didominasi oleh lahan perikanan darat dimana dalam konsep telapak ekologis merupakan lahan dengan tingkat keberlanjutan yang rendah (konversi biokapasitas kecil).

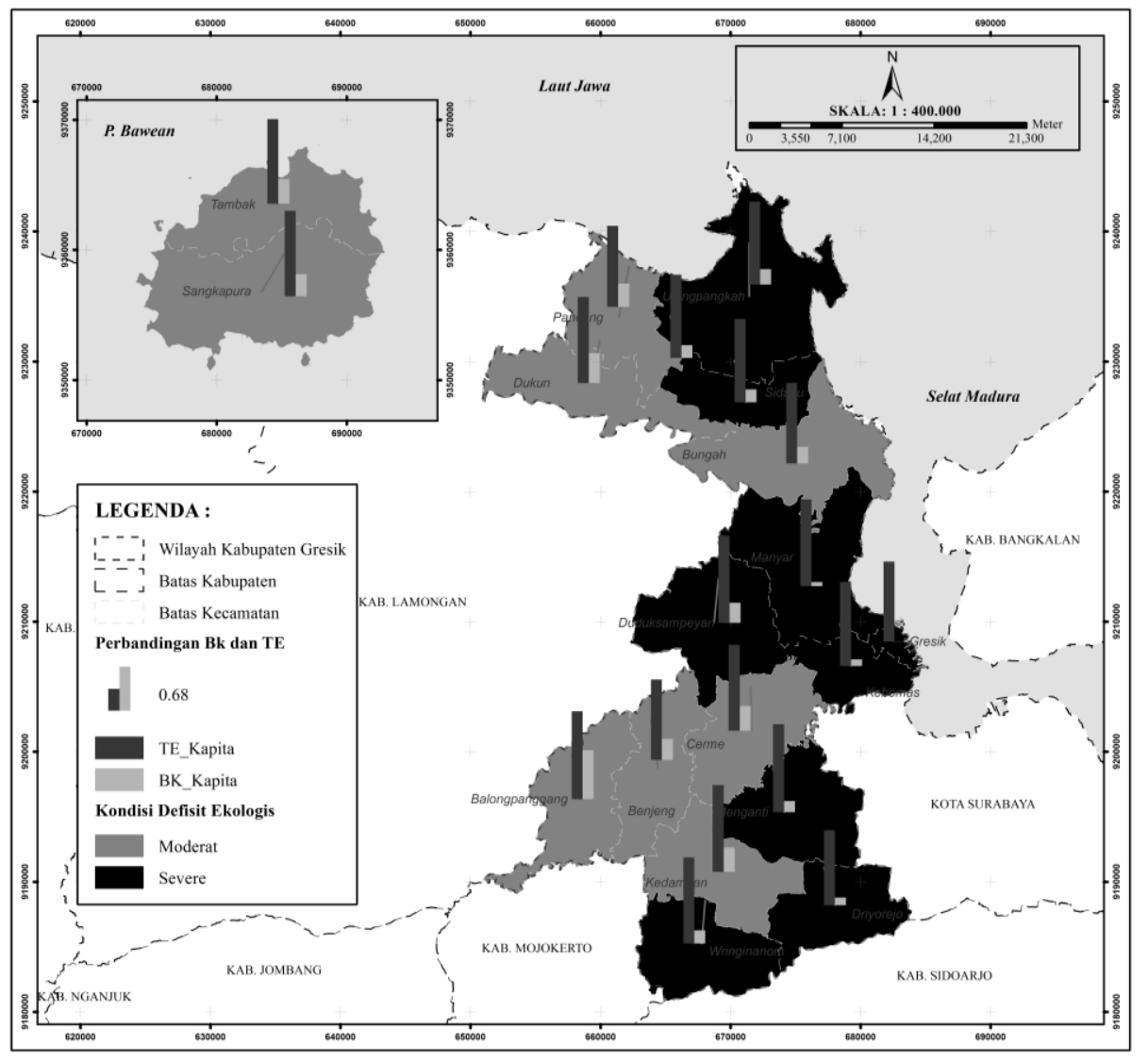

Gambar 3. Tipologi Keseimbangan Ekologis Masing-Masing Kecamatan di Kabupaten Gresik 


\section{Arahan Optimasi Penggunaan Lahan Melalui Pendekatan Telapak Ekologis di Kabupaten Gresik}

\section{Arahan Optimasi Penggunaan Lahan di Kabupaten Gresik}

Pada Gambar 3 semakin memperkuat intensitas kegiatan yang tinggi di daerah perkotaan menimbulkan konsentrasi jumlah penduduk yang tinggi sehingga konsumsi sumber daya alam juga semakin meningkat. Pada Gambar 3 yang menunjukkan kelompok-kelompok wilayah sehingga optimasi lahan perlu diarahkan pada kelompok tersebut. Pada kelompok 1 yang merupakan kelompok perkotaan terdiri dari Kecamatan Gresik, Manyar, Kebomas, Duduksampeyan, Menganti dan Driyorejo perlu sebuah penanganan pembangunan yang optimal salah satunya dengan penerapan kota kompak sehingga pertumbuhan lahan terbangun memusat dan terjadi efisiensi penggunaan energi dan lahan terbuka dapat dipertahankan.

Pada kelompok kedua yang merupakan wilayah perdesaan yang terdiri dari dua bagian. Bagian pertama merupakan bagian selatan terdiri dari Kecamatan Balongpanggang, Cerme, Benjeng, dan Kedamean dapat diarahkan pada peningkatan lahan pertanian. Hal ini dikarenakan bioproduktifitas lahan pertanian yang tinggi di wilayah ini seperti hasil analisis biokapasitas. Peningkatan produktifitas lahan pertanian perlu dilakukan untuk men-supply kebutuhan pangan yang tinggi pada daerah perkotaan. Bagian kedua addalah wilayah perdesaan bagian utara yang terdiri dari Kecamatan Dukun, Bungah, Sidayu, Ujungpangkah, dan Panceng. Wilayah ini memiliki biokapasitas lahan pertanian, perikanan dan kehutanan yang tinggi sehingga peningkatan produktifitas lahan perikanan dan pertanian dapat menjadikan wilayah ini sebagai sumber supply.

\section{Kesimpulan dan Rekomendasi}

\section{Kesimpulan}

Dari paparan diatas dapat disimpulkan sebagai berikut :

1. Komponen optimasi lahan berdasarkan pendekatan telapak ekologis terdiri dari biokapasitas dan telapak ekologis masing-masing kategori lahan.

2. Kondisi daya dukung Kabupaten Gresik secara keseluruhan dalam keadaan defisit dimana tingkat konsumsi penduduk Kabupaten Gresik terhadap sumber daya yang ada di Kabupaten Gresik melebihi kapasitas lahan dalam menghasilkan sumber daya alam.

3. Tingkat konsumsi lahan yang dibutuhkan penduduk Kabupaten Gresik untuk memenuhi kebutuhannya adalah sebesar 1,639,282.63 gha dari lahan telapak ekologis yang ada, sedangkan biokapasitas lahan yang tersedia untuk penduduk Kabupaten Gresik sendiri sebesar 319,179.06 gha.

\section{Rekomendasi}

1. Pembangunan yang berbasis kota kompak yang memusat pada wilayah perkotaan Kabupaten Gresik perlu diadopsi dalam penataan ruang.

2. Peningkatan produktifitas lahan dan penataan ruang baik melalui penerapan agropolitan pada wilayah perdesaan dapat menjadikan wilayah perdesaan sebagai sumber bioproduktifitas Kabupaten Gresik tanpa megurangi pembangunan di wilayah perdesaan. 


\section{Daftar Pustaka}

Arsyad, Sitanala, dkk. 2008. Penyelamatan Tanah, Air dan Lingkungan. Jakarta: Crestpent Press dan Yayasan Obor Indonesia

Borucke, Michael. 2013.Accounting for demand and Supply of the Biosphere's regenerative capacity : The national Footprint Account's underlying methodology and Framework. Elsevier: Ecological Indicators Vol 24 Tahun 2013. www. Elsevier.com

Constanza, Robert. 2000. The Dynamics of The Ecological Footprint Concept. Elsevier: Ecological Economics Vol. 32 Tahun 2000. www. Elsevier.com

Dinas Pertanian, Perkebunan dan Kehutanan. 2011. Rekap Luas Panen Produksi dan Produktivitas Padi, Palawija Tahun 2000-2009

Dinas Pertanian, Perkebunan dan Kehutanan. 2011. Data Pertanian, Perkebunan dan Kehutanan Kabupaten Gresik 2010

Dinas Pertanian, Perkebunan dan Kehutanan. 2011. Data Pertanian, Perkebunan dan Kehutanan Kabupaten Gresik 2011

Dirjen PU, Kementrian Pekerjaan Umum. 2010. Kajian Telapak Ekologis Di Indonesia. Jakarta

, Kementerian Pekerjaan Umum. 2011. Kajian Telapak Ekologis Kawasan Perkotaan. Jakarta

Global Footprint Network, 2012. National Footprint and Biocapacity Accounts, 2011 Edition. Available at http://www. Footprintnetwork.org

Irwan, Zoeraini Djamal. 2005. Tantangan Lingkungan dan Lansekap Hutan Kota. Jakarta : Bumi Aksara

Kodoatie, Robert. 2005. Pengelolaan Sumber Daya Air Terpadu. Yogyakarta: ANDI Yogyakarta

Kodoatie, Robert J dan Sjarief, Roestam. 2010. Tata Ruang Air. Yogyakarta: Penerbit ANDI.

Prasita, Djanat. 2007. Analisis Daya Dukung Lingkungan dan Optimalisasi Pemanfaatan Wilayah Pesisir Untuk Pertambakan di Kabupaten Gresik. Penelitian Disertasi. Bogor: Institut pertanian Bogor

Retnowati, Inge. 2011. Kajian Telapak Ekologis: Pertimbangan Untuk Strategi Pembangunan Berkelanjutan.

RTRW Kabupaten Gresik Tahun 2010-2030

Rusli, Said, dkk. 2010. Tekanan Penduduk, Overshoot Ekologi Pulau Sumatera dan Masa Pemulihannya. Jurnal Transdisiplin Sosiologi, Komunikasi dan Ekologi Manusia Vol. 4 No. 1 April 2010.

Soemarwoto, Otto. 2004. Ekologi, Lingkungan Hidup dan Pembangunan. Jakarta: Djambatan

Soeriatmaja. 1981. Ilmu Lingkungan. Bandung: Penerbit ITB

Wackernagel, M., Rees, W.E., 1996. Our ecological footprint. Reducing Human Impact on the Earth. New Society Publisher, Gabriola Island, Canada.

Widiatmaka, Sarwono. 2007. Evaluasi Kesesuaian lahan dan Perencanaan Tata Guna Lahan. Yogyakarta: Gajah Mada University Press 
78 Arahan Optimasi Penggunaan Lahan Melalui Pendekatan Telapak Ekologis di Kabupaten Gresik

JURNAL WILAYAH DAN LINGKUNGAN, 1 (1), 67-78 